TITLE:

\title{
A large landslide triggered by the 2008 Wenchuan (M8.0) earthquake in Donghekou area: Phenomena and mechanisms
}

\section{$\operatorname{AUTHOR}(S)$ :}

Wang, Gonghui; Huang, Runqiu; Lourenço, Sérgio D.N.; Kamai, Toshitaka

\section{CITATION:}

Wang, Gonghui ... [et al]. A large landslide triggered by the 2008 Wenchuan (M8.0) earthquake in Donghekou area: Phenomena and mechanisms. Engineering Geology 2014, 182(B): 148-157

\section{ISSUE DATE:}

2014-11

URL:

http://hdl.handle.net/2433/192897

\section{RIGHT:}

(c) 2014 Elsevier B.V.; この論文は出版社版でありません。引用の際には 出版社版をご確認ご利用ください。; This is not the published version. Please cite only the published version. 


\title{
A large landslide triggered by the 2008 Wenchuan (M8.0) earthquake in Donghekou area: phenomena and mechanisms
}

\author{
Gonghui Wang $^{1)}$, Runqiu Huang ${ }^{2)}$, Sérgio D.N. Lourenço ${ }^{3)}$, Toshitaka Kamai $^{1)}$ \\ ${ }^{1)}$ Research Center on Landslides, Disaster Prevention Research Institute, Kyoto University, Uji, Kyoto, Japan. \\ E-mail: wanggh@landslide.dpri.kyoto-u.ac.jp; Tel: 81-774384115; Fax: 81-774-384300 \\ ${ }^{2)}$ State Key Laboratory of Geo-hazard Prevention and Geo-environment Protection, Chengdu University of \\ Technology, Chengdu, P.R. China \\ 3) The University of Hong Kong (Formally School of Earth and Ocean Sciences, Cardiff University, United \\ Kingdom)
}

\section{ABSTRACT:}

During the 2008 Wenchuan earthquake, more than 60,000 landslides were triggered, resulting in about 20,000 casualties. Among these landslides, a catastrophic one occurred in Donghekou area of Qingchuan County. Donghekou landslide had a volume of about $1 \times 10^{7} \mathrm{~m}^{3}$, traveled fast for approximately $2 \mathrm{~km}$, killing about 780 people. The source area consisted of unstable sedimentary strata and the runout path was made of colluvial deposits. During the earthquake, the colluvial deposits started to move first, before the arrival of the displaced landslide debris from the main source area. We performed undrained cyclic ring shear tests on samples taken from the runout path and concluded that liquefaction of the runout path material enhanced the mobility of the debris material. A fumarole was identified on the upper part of the runout path 6 months later. We analyzed the gas and water venting out, and concluded that the fumarole was not the result of fault movement; it resulted instead from the weathering of slate from the source area. The long-travel landslide materials blocked two rivers, forming two landslide dams that breached with the occurrence of overtopping. To better understand the internal structure of the landslide deposits and then provide evidence for a rational plan of countermeasures to stabilize the landslide dams, we measured the shear-wave-velocity of the landslide deposits by a surface-wave technique called multichannel analysis of surface waves (MASW). The results revealed that the landslide dams consisted 
of loosely deposited debris, suggesting that the landslide dams were mechanically weak and prone to erosion by overtopping.

Keywords: Wenchuan earthquake, catastrophic landslide, liquefaction, internal structure, weathering of slate

\section{Introduction}

On May 12 2008, at 14:28 local time, an earthquake (M8.0) occurred at $30.986^{\circ} \mathrm{N}, 103.364^{\circ} \mathrm{E}$ in Sichuan province, China (USGS, 2008). Named Wenchuan earthquake, after the earthquake's epicenter in Wenchuan County, Sichuan province (Fig. 1), the epicenter was $80 \mathrm{~km}$ west-northwest of Chengdu, the capital of Sichuan, with a hypocenter at a depth of $19 \mathrm{~km}$. The earthquake was felt as far away as Beijing (1500 km away) and Shanghai (1700 km away), and also in some nearby countries. Strong aftershocks continued to hit the area after one year of the main earthquake, causing new casualties and damage.

The Wenchuan earthquake caused heavy losses in both built infrastructure and human lives. According to the official reports (CCTV, 2008), as of September 8 2008, 69,226 people were confirmed dead, 374,643 injured, and 17,923 missing. The earthquake left an estimated 4.8 million people homeless, although the number could be as high as 11 million. Approximately 40 million people were affected.

The collapse of buildings during the earthquake was the main reason for the casualties. There were more than 60,000 landslides triggered by the quake (Dai, et al. 2011a; Gorum et al. 2011). Roads to the mountainous areas were blocked and many natural dams were formed by the landslide debris, resulting in logistic challenges for the rescue activities (Fan et al. 2012; Peng et al., 2014), and also continuously resulting in secondary disaster to the locals (Tang et al., 2011; Huang \& Fan, 2013; Hu et al. 2014; Yu et al., 2014; Zhang et al., 2013; Zhang et al., 2014a, Zhang et al., 2014b). The variety of landslides along the $280 \mathrm{~km}$ fault rupture line (Fig. 1) made this 
event particularly useful for better understanding co-seismic landslides.

To date, several studies have identified the types and distribution of landslides triggered by the Wenchuan earthquake (Huang, 2009; Huang and Li, 2009; Huang and Fan, 2013; Xu et al., 2009; Qi et al., 2010; Dai, et al. 2011a; Gorum et al. 2011; Tang et al. 2011). Main landslide types include shallow landslides, rock falls, deep-seated landslides, and rock avalanches (Dai et al., 2011b). The triggering mechanisms of some large landslides has been linked to strong seismic ground motion (Huang, 2009; Xu et al. 2009; Yin et al. 2009; Zhang et al., 2013) or fault rupture (e.g., Xu and Tang, 2009; Dai et al. 2011b). The high mobility of some large landslides has been related to the high initial velocity of the displaced landslide materials immediately after failure (Chen, 2009; Xu et al., 2009; Yin et al. 2011; Yuan et al., 2013). Also, the high mobility of some landslides (e.g., the Niumiangou and Xiejiadian landslides) has been associated to the decreased shear resistance of the runout path materials due to, (1) air cushioning beneath the moving debris (Yin et al. 2011) and (2) the generation of high excess pore-water pressure (Chigira et al. 2010; Wang et al., 2013). Wang et al (2013) described a flow-type of landslide occurring in Xiejiadian area of Pengzhou city that caused about 100 casualties, and concluded that liquefaction of runout path material greatly enhanced its mobility. Although the number of large, fast-moving landslides is limited, their damage was severe, because the urbanized were located downstream, in low lying areas. The landslide under study in this paper occurred in Donghekou area of Qingchuan County (hereinafter referred to as the Donghekou landslide), killed about 780 people, destroyed four villages downstream, and blocked two rivers. Donghekou landslide is a rockslide-debris avalanche (as defined by Hungr and Evans (2004)) with the runout path material entrained by the impact of rock debris (e.g., Wang et al. 2009a; Dai et al. 2011b; Yin, et al.2009, 2011; Sun et al., 2009a,b; Wang et al., 2012). From a detailed field investigation, laboratory tests and local people witness accounts, we show in this paper that the runout path 
materials liquefied during the main shock, greatly enhancing the mobility of the landslide materials.

As the result of the landslide, two landslide dams were formed, blocking a river and its tributary, but later collapsed due to water overtopping. Different types of countermeasures were repeatedly performed to stabilize the landslide dams, however, they were proven ineffective due to damage during the subsequent heavily rainfall events. Therefore, an improved understanding of the geotechnical properties of the landslide dams and their inner structure is of great importance for an effective design of the countermeasures. With this aim, we used shear-wave velocity methods to provide a spatial insight into the landslide dams.

The appearance of a fumarole at the upper part of the runout path 6 months later was also questioned. In particular, whether there was any relation with the landslide or a mapped geological fault running in this area. Therefore, this paper aims to: (1) identify the main characteristics of the Donghekuo landslide and, (2) to identify and examine the possible mechanisms that lead to these characteristics. Not only will this study contribute to the science behind earthquake-triggered landslides or large size, it will also contribute towards the risk assessment of the resulting deposits.

\section{Geological setting}

The earthquake occurred on the Longmenshan thrust zone, which is located on the eastern boundary area of the Tibet plateau, and is one of the significantly deformed regions in the Chinese continent with many seismically active faults (Burchfiel et al., 1995, 2008; Jia et al., 2006, 2007; Densmore et al., 2007). The continuing northward indentation of the Indian plate into the Tibetan crust after the collision between the Indian and Eurasian plates induced uplift and deformation of the Tibetan Plateau. The Longmenshan thrust zone is about 60 $\mathrm{km}$ wide, and constitutes the topographic boundary between the eastern Tibetan Plateau and the Sichuan basin. 
The convergence rate across the thrust zone is inferred to be 4-6 mm/yr (Deng et al. 1994; He \& Tsukuda 2003).

The elevation of the area affected by the quake varies from 1000 to $4500 \mathrm{~m}$ on the west side of Chengdu basin.

Earthquakes occur frequently along this zone. For example, in 1933, a M7.5 earthquake occurred in Diexi, 50

km northeast of Wenchuan, and in 1976, two earthquakes (M7.2) occurred in Songpan and Pingwu, northeast of

Chengdu.

According to the geologic map of the Sichuan earthquake area (Ma, 2002), the Longmenshan thrust zone mainly occurs within granite, metamorphic sandstone, phyllite, sandy slate and dolomite (Fig. 2). These rocks range from Precambrian to Cretaceous in age. The rocks are fragmented due to the strong tectonic movement in this area. However, the Chengdu basin has been less affected and remained relatively stable throughout the Cenozoic. Quaternary alluvium overlies strata of the Jurassic and Cretaceous Periods within the basin.

\section{Donghekou landslide}

Donghekou landslide is located in Donghe Village, Qingchuan County, about $250 \mathrm{~km}$ northeast of Chengdu. Fig. 3a presents an oblique aerial view of the landslide. Fig. $3 \mathrm{~b}$ shows a view from the toe of the landslide before the earthquake. Fig. $3 \mathrm{c}$ is the longitudinal section along line I-I' in Fig. 3a. The bedrock geology in the vicinity of the landslide is mainly composed of dolomite, limestone, sandstone, carbon siliceous slate, and phyllite. The landslide originated from a slope along the confluence of Qinzhu River and its tributary, Hongshi River. A fault passing through the source area has been identified (Xu and Tang, 2009; Yu et al., 2010; among others). The hard rock geology, to the left side of the fault (when facing the slope), is mainly composed of limestone, whereas to the right side it is composed of strongly weathered slate, which is the main source material of the landslide. Large extension cracks have been identified to the left side of the source area. The local population was made aware of slope instability and evacuation was enforced during heavy rainfall events, but not prior to the 
unexpected earthquake. The displaced mass had a total volume of $1 \times 10^{7} \mathrm{~m}^{3}$ and developed into a debris flows after initiation. It traveled downslope for about $2 \mathrm{~km}$ with an elevation drop of about $500 \mathrm{~m}$, passing through residential areas before being deposited on a rice paddy. Four villages were buried completely, and about 780 people were killed. Both rivers were obstructed by the debris, creating a dam about $700 \mathrm{~m}$ long, $500 \mathrm{~m}$ wide and 15-25 m high. The resulting impoundment overflowed after a few days, followed by partial collapse of the dam. No casualties were registered in the downstream villages.

The long travel distance of the landslide through the residential area and rice paddy at the bottom of the slope, which is near horizontal, suggests the movement of the landslide was extremely fast. This was confirmed by local eyewitness accounts which reported first hearing an 'explosion' from the ground three times, followed by very strong vertical ground vibration with a continuous loud noise and a cloud of dust. When the dust settled, all they could see was a debris landscape. Their belief was that the debris 'emerged from the ground'.

We surveyed several landslides triggered by the Wenchuan earthquake and found that in some landslides the colluvium on the runout path material had liquefied and "flowed" downstream only due to the seismic motion. This suggested the colluvium at the valley on area B1 (shown in Fig. 3b) had liquefied during the main shock of the earthquake. The materials on the valley might have started its movement almost at the same time as that on the upper slope (area B2 and B3 in Fig. 3b). This inference was supported by a local who was working on the field, at location 'W' in Fig. 3b, when the earthquake occurred. He reported, sliding down the valley in area B1 and moving materials from area B2, which was followed by the downslope movement of the "mountain" in area B3. Other local eyewitness accounts suggest failures on the source area continued for two days.

Fumaroles appeared on the middle part of the landslide (area B1) 6 months after the earthquake (Fig. 4a). In the 
fumarole opening, the ground temperature was elevated (Fig. 4b) and the air had a sulfurous smell. Fumes emanating from the area could be seen at distance in the first two years but at present are only visible in cold weather.

Countermeasures were performed to stabilize both the bank slope along Qingzhu River and the channelized stream on the landslide dam blocking Hongshi River. However, nearly all the structures were badly destroyed at each heavy rainfall event. Although these structures had been repaired or completely rebuilt each time, they were ineffective mainly due to the fact the material comprising the landslide dam was easily eroded by overtopping.

Donghekou landslide area was designated an earthquake ruins park soon after the earthquake. The park was opened in November 2008 with a memorial and a museum built on the landslide deposit area. However, the park was severely disrupted by debris flows almost every year. Despite being rebuilt several times, it was moved offsite to a nearby local town (about $3 \mathrm{~km}$ downstream of Qingzhu River).

\section{Method}

To clarify the nature and the source of the venting fumarole, we sampled liquid and gas from the opening, and analyzed the chemistry of the fume in the laboratory. We selected two fumaroles at different locations and measured the temperature at 1-m deep with a 1-m long pipe. Measurements were done three times per day (morning, noon and evening) from May 212009 to November 202009 by a local resident with a digital thermometer with a resolution of $0.1^{\circ} \mathrm{C}$.

To infer the movement characteristics of the displaced landslide materials and also the stability of the landslide dams, we examined the internal structure and characteristics of the landslide deposits by a surface-wave survey method known as multichannel analysis of surface waves (MASW) (Park et al., 1999; Hayashi and Suzuki, 
2004). Shear-wave velocity (Vs) profiles were determined for the landslide deposits. The survey principle of

MASW and the layout of equipment (Seismograph: Model McSEIS-SXW, OYO Corporation, Tokyo, Japan;

Geophones: Model GS-11D, OYO Geospace Corporation, Houston, Texas, USA) has been outlined in Wang et al (2013b). The geophones used in the MASW survey had a natural frequency of $4.5 \mathrm{~Hz}$. The survey had been performed along four lines (L1, L2, L3, and L4 in Fig. 3). L1 was along the road running parallel to the drainage channel of Honshi River, and was surveyed in July of 2008. One year later, engineering works were performed to stabilize this drainage channel resulting in a flat L2 bank, which enabled us to survey the Vs profile in November 2009. Other two lines were surveyed in September 2009. L3 was along the longitudinal direction on the central part of the deposit area. L4 was measured along a road constructed after the earthquake, on a cut slope to the right of the deposit area. From the topography of slope where the road was constructed, we inferred that the part of this survey line (about $20 \mathrm{~m}$ far from the origin) crosses a relic landslide. Hereinafter, we call these survey lines L1, L2, L3, and L4, respectively.

To examine whether the deposits on the toe part of the slope were liquefiable under earthquake motion, we took samples of sandy soils from the deposit area and from the side slope on the runout path, and performed saturated cyclic shear tests under undrained condition by means of a ring shear apparatus developed at the Disaster Prevention Research Institute (DPRI), Kyoto University (Sassa et al., 2003).

\section{Results and discussion}

\subsection{Ground temperature of fumarole and fume composition}

The temperature measured at noon was usually $0.2^{\circ} \mathrm{C}$ higher than in the morning or in the evening of the same day. Irrespective of these small differences, we used the average of three measurements to compute the daily temperature. Fig. 5 presents the 1-m deep ground temperature measured at the two locations. Data for the period 
of July 15-24 is missing, because heavy rainfall during July 15-19 obstructed the access to the measurement points due to flooding in the landslide area. During the first measurement period (from May 21 to July 14), the ground temperatures were about $58^{\circ} \mathrm{C}$ and $56^{\circ} \mathrm{C}$ for $\mathrm{P} 1$ and $\mathrm{P} 2$ locations, respectively. However, the temperatures on July 25 (after the heavy rainfall) elevated to $63^{\circ} \mathrm{C}$ and $65^{\circ} \mathrm{C}$ for $\mathrm{P} 1$ and $\mathrm{P} 2$ locations, respectively, slowly decreasing with time thereafter. In November 1, the pipes for temperature measurement were lost and two new holes (about $80 \mathrm{~cm}$ in diameter and $1 \mathrm{~m}$ deep) were dug for the new measurements. This resulted in a sudden drop in the measured temperature at both locations on November $1^{\text {st }}$. Nevertheless, the temperature remained approximately the same afterwards. Although we ceased the temperature measurements by November 202009 , on our last visit in July 19 2012, the fumarole locations were still with elevated temperatures comparing to the wider landslide area.

Analysis on the liquid and gas collected from the vents revealed that the major elements presented in the liquid samples were K (128.9 ppm), Na (7.1 ppm), Ca (3112 ppb), Mg (475.2 ppb), B (377.6 ppb), Ba (163.7 ppb), and $\mathrm{Zn}(151.1 \mathrm{ppb})$, while the gas was mainly consisted of $\mathrm{CO}_{2}(7.6-8.3 \%)$ and Methane (3ppm).

The fault, indicated in the geological maps for the Donghekou, crosses the source area of the landslide (Xu and Tang, 2009; Yu et al., 2010). Xu and Tang (2009) claims the fault ruptured during the earthquake possibly playing a key role in the initiation of the landslide. Therefore, it is reasonable to infer that the fumes might have resulted from the fault rupture, because gas emissions due to the occurrence of earthquake have been widely reported in the literature, and similar phenomena has been found elsewhere during the Wenchuan earthquake. For instance, Zhou et al (2010) analyzed the geochemistry of soil gas in the seismic fault zone produced by the Wenchuan earthquake, and found that the magnitudes of the $\mathrm{He}$ and $\mathrm{H}_{2}$ anomalies declined significantly with decreasing strength of the aftershocks with time, with the anomalies of $\mathrm{He}, \mathrm{H}_{2}, \mathrm{CO}_{2}$, and $\mathrm{Hg}$ concentrations 
related to the variation in the regional stress field and the aftershock activity. Gas emissions were also found on the Qingzhu River (about $3.2 \mathrm{~km}$ on the upper stream of Donghekou landslide area) immediately after the Wenchuan earthquake. Zheng et al (2013) found that the predominant gases are $\mathrm{CH}_{4}$ (a usual gas released from faults), $\mathrm{CO}_{2}, \mathrm{~N}_{2}$ and $\mathrm{O}_{2}$; the $\mathrm{N}_{2}, \mathrm{O}_{2}$ and noble gases are of atmospheric origin, while $\mathrm{CH}_{4}$ and $\mathrm{CO}_{2}$ have typical biogenic signatures; and they concluded that the gases are discharged from a shallow reservoir through faults or fractures caused by the earthquake, but no direct pathways (such as faults or factures) connecting the surface and the natural gas reservoir were formed.

Oxidization of coal and other combustible materials can result in spontaneous combustion, a phenomenon that had been widely reported occurring in coal refuse. Because coal and the carbonaceous minerals which form the major component of most refuse begin to oxidize as soon as they are exposed to the atmosphere (Maneval, 1969), spontaneous combustion occurs when sufficient air enters the refuse to oxidize the coal and other combustible materials. Sun et al (2009) studied the rocks in Donghekou landslide area and reported that the carbonaceous siliceous slate in Donghekou landslide area consists mainly of $17 \%$ of carbon, $52 \%$ of quartz, and $31 \%$ of white mica. Therefore, it is reasonable to infer that the carbonaceous minerals in the slate will suffer quick oxidization once they are outcropped. On the other hand, the carbonaceous siliceous slate was rich in sulfide minerals, which can be oxidized quickly when exposed to the atmosphere or underground to water with oxygen. In the study of weathering process of black rock formations, Zhu and $\mathrm{Wu}$ (2012) reported that the biological and chemical oxidation would result in the production of sulfur; the dissolution of the calcium carbonate from the slate in acidic conditions would result in the emission of $\mathrm{CO}_{2}$, and decomposition reaction of the major minerals would result in the production of $\mathrm{Na}, \mathrm{K}, \mathrm{Ca}, \mathrm{Mg}, \mathrm{Zn}, \mathrm{Ba}$ and others. 
From the facts above and as the fumes occurred only in areas where blocks of carbonaceous siliceous slate were deposited, instead of associating the fume with fault rapture, we inferred that weathering of the slate was the main reason for the occurrence of the fumarole. Fig. 4c shows a photo of weathered slate taken in July 19, 2012 at the fumarole location. Further evidence of sulfur deposits is shown in Fig. 4d. The sudden increase in the ground temperature in July 2009 could have been due to the oxygen-saturated rainfall which accelerated the weathering process.

\subsection{Internal structure of landslide deposit}

Fig. 6 presents the shear-wave velocity (Vs) profile along survey line L4. As mentioned previously, L4 was conducted along a road in a cut slope. The obtained shear-wave velocity profile represents the undisturbed slope i.e. no landslide was initiated during the earthquake. However, because part of L4 enters the main body of an old landslide (Fig.6a), the material near of the origin of the survey line showed greater Vs values (ranging from $300-470 \mathrm{~m} / \mathrm{s}$ ) than those inside the landslide body (with small Vs values ranging from $250-290 \mathrm{~m} / \mathrm{s}$ ). The higher value of Vs represents the bedrock, while the smaller value of Vs may represent the landslide debris. The boundary with a strong contrast in Vs may represent the sliding surface. The results in Fig. 6 evidence the effectiveness of using MASW to identify the sliding surface of a landslide.

The shear-wave velocity (Vs) profiles along L2 and L1 are presented in Figs.7a and 7b, respectively. These two lines are parallel to the drainage channel but distanced $70 \mathrm{~m}$ apart. As shown in Fig. 7b, the upper layers are weaker, with smaller Vs values ranging from 250-300 m/s, with their thickness increasing away from the origin of the survey line. However, these layers are separated by a harder layer with greater Vs values (ranging from $300-340 \mathrm{~m} / \mathrm{s}$ ), which allows us to divide the profile into three sub-zones. This harder soil layer/horizon might result from isolated blocks of rock in a matrix of landslide debris. Three layers with Vs ranging from 330-470 
$\mathrm{m} / \mathrm{s}$ can be identified in the bottom of the profile. These layers can be regarded as the original ground where a road was located before the earthquake. Therefore, the boundary showing large contrasts in Vs could be regarded as the boundary between the landslide debris and original ground. The Vs profile along L2 (Fig. 7a) showed that the weak soil layer $(\mathrm{Vs}=250-300 \mathrm{~m} / \mathrm{s})$ is thicker than $\mathrm{L}$, with the landslide deposits extending beyond $20 \mathrm{~m}$ depth (the maximum depth reached by the survey). It can be noticed that a harder soil layer/horizon was also enclosed in the weaker upper soil layer, with their locations matching L1. This suggested the harder layer/horizon of isolated rocks blocks extended beyond $100 \mathrm{~m}$.

The shear-wave velocity along the longitudinal section of the deposit area showed that the superficial soil layers have small $\mathrm{V}_{\mathrm{s}}$ values (ranging from 180-270 m/s) (Fig. 8). The contrasts in the $\mathrm{V}_{\mathrm{s}}$ values indicated that the landslide deposits may have a thickness of about $10 \mathrm{~m}$ in average, and the displaced materials on the deposit area are consist mainly of rock debris. There is a region at the center of the survey line, 110-140 m, at 7-10m depth, where the shear velocity is greater (ranging from 300-360 m/s). This region may correspond to isolated large blocks in the landslide debris matrix. In this area, a large number of big boulders, sized 2-3m, were deposited. The superficial soil layers with lower Vs values in the rear part of this region may have resulted from particle segregation. It is well known that due to particle segregation during the movement of rock avalanches and debris/pyroclastic flows, large-sized particles normally accumulate at the front and top surface whilst smaller particles accumulate at the bottom and rear part of the flowing material. Zhang et al (2011) measured the bulk densities of superficial deposits at different locations of Donghekou landslide, and found that the bulk density varied along the runout path. Fig.8 shows the results with the origin of the horizontal distance being approximately the same as our survey line L3. As seen, the variation of bulk density is consistent with the shear-wave velocity profile, where the origin area has the lowest bulk density. This may explain the easy 
breaching of the landslide dams by overtopping.

\subsection{Geotechnical properties and landslide mobility}

Geotechnical test conditions were designed to represent a soil element on the sliding surface overlain by a soil layer about $17.5 \mathrm{~m}$ thick (Fig. 9a), according to the longitudinal section shown in Fig. 3e. The normal and shear stresses on the sliding surface were therefore calculated using a slope angle of 17 degrees and a saturated unit weight of $18 \mathrm{kN} / \mathrm{m}^{3}$. We calculated the normal stress and shear stress without considering the possible ground water table above the sliding surface, although it is reasonable to assume that most soil layers above the sliding surface were saturated. Thus, the estimated total normal stress was $300 \mathrm{kPa}$ and static shear stress was $92 \mathrm{kPa}$. After being saturated and normally consolidated, the samples were sheared by applying the cyclic loading (see Fig. 9b) under undrained conditions.

The undrained cyclic shear test results are presented in Fig. 10. The sandy soils revealed a sharp reduction in shear resistance during the cyclic shearing achieving a low residual shear strength (about $5 \mathrm{kPa}$ ). This gives an apparent mobilized friction angle of about 1 degree $(\arctan (5 / 300)$. Although the monitored excess pore-water pressure showed a delayed response, it reached a constant pore water pressure of $280 \mathrm{kPa}$, resulting in an effective normal stress of $20 \mathrm{kPa}$, indicating that this runout path material is highly liquefiable.

Several interpretations had been proposed to explain the long runout movement of Donghekou landslide. For instance, Huang (2009), Wang et al. (2009), Xu and Tang (2009), and Yin et al. (2009) suggested that strong earthquake motion on the landslide source area (due to topography effects) may have enabled the displaced landslide debris to become highly mobile. The large elevation difference between the source area and the river may have enhanced the mobility and travel distance by converting the large stored potential energy into kinetic 
energy. On the other hand, other factors may have contributed to the long runout movement, in particular, liquefaction phenomenon occurring on the landslide material on the source area during the main shock of the earthquake (Wang et al., 2012) and liquefaction occurring on the valley deposits due to the impact force by the landslide debris from the upper slope (Sun et al., 2009b; Wang, et al., 2012). An air cushion effect has also been considered (Yin, 2009; Sun et al., 2009).

Acknowledging the high mobility nature of Donghekou landslide, Li et al. (2012) simulated its kinematic behavior, and concluded that a low friction coefficient (about 0.1 ) is required to justify its mobility. Zhou et al (2013) concluded that the maximum amplification coefficient of dynamic acceleration for the Donghekou landslide is approximately 3.909, and the sliding mass was triggered with a small initial velocity when it detached from the upper slope.

From the above, a variety of initiation and movement mechanism have been proposed for Donghekou landslide.

Nevertheless, based on our field survey on some landslides triggered by Wenchuan earthquake and experiment results shown in Fig. 10, we conclude that during the earthquake the liquefaction of sandy layers resulted in the movement of valley deposits in area B1, prior to the arriving of landslide debris from the upper slope. The liquefied materials and the abundance of water from the river elevated the mobility of the displaced materials from the upper slope further enhancing the rapid long-travel movement. In this regard, our findings are in agreement with those of Sun et al (2009) and Wang et al (2012). However, we concluded that the materials on the valley were liquefied by the earthquake prior to them being overridden by and incorporated in the material derived from area B2 and B3 in Fig. 3. This has implications in the assessment of landslide risk during earthquakes. Liquefaction of saturated runout-path materials resulting from seismic ground motion should be 
included in the analysis of coseismic landslide dynamics because they enhance the mobility of the displaced landslide materials. Similar phenomenon has also been reported in some other landslides triggered by Wenchuan earthquake (Wang et al., 2013a).

Dunning and Armitage (2011) pointed out that rock-avalanche deposits generally exhibit three sedimentary facies: a carapace facies (the coarsest unit composing the surface and near surface), a body facies (the main body of the rock-avalanche deposit), and a basal facies (the base of the rock-avalanche deposit). Wang et al (2013b) identified a clear boundary between the basal facies and the body facies through the case study on a rockslide occurring on Tianchi area, Sichuan, during the same earthquake, and suggested that the superficial layer (carapace facies) and the bottom layer (basal facies) have relatively smaller shear-wave velocities values. Nevertheless, similar basal facies was not found in Fig. 10. These differences might result from different movement mechanisms. For instance, Tianchi rockslide mainly involved the movement of dry rocks, while Donghekou landslide involved in the movement of liquefied runout path material with dry rocks/debris displaced from the source area.

\section{Conclusions}

The 2008 Wenchuan earthquake (M8.0) was one of the most catastrophic geohazards to occur in the world during the $21^{\text {st }}$ century. Besides its great damage to human life, private property, and built infrastructure, it also triggered numerous landslides, leading to thousands of casualties. Among these catastrophic landslides, Donghekou landslide was representative of other large landslides, with a total volume of about $1 \times 10^{7} \mathrm{~m}^{3}$ and a travel distance of about $2.0 \mathrm{~km}$ with an elevation drop of about $500 \mathrm{~m}$. Four villages were buried by the debris, 780 people were killed, and two rivers were dammed by the displaced landslide materials. To understand the 
resultant phenomena such as the formation of landslide dams, occurrence of fumaroles, and the high mobility nature of the displaced landslide materials, we performed field and laboratory investigations. The results are summarized as follows.

(1) Donghekou landslide evolved in a retrogressive style. The runout path material and the main landslide material from the upper slope started to move almost at the same time when the earthquake occurred, followed by the upper slope.

(2) Occurrence of venting fumes on the deposit area resulted from the weathering of the underlying landslide materials and bedrock (slate), and not the result of fault movement. The slate originated from the source area and deposited on the toe. Weathering of the slate resulted in the fume.

(3) A seismic geophysical survey of the landslide deposits revealed that the soil layers were not homogenous. The superficial layer has relatively smaller shear-wave velocities values. Some regions of the central part of the deposits show relatively greater shear-wave velocities.

(4) The soil layers along the runout path are highly liquefiable. The liquefied runout path materials enhanced the mobility of the displaced materials from the upper part of the slope, leading to the formation of loose deposits.

\section{Acknowledgement}

This research was partially supported by (1) the Opening Fund of State Key Laboratory of Geohazard Prevention and Geoenvironment Protection (Chengdu University of Technology) (Nos. GZ2009-02), and (2) the scientific research grants from the MEXT of Japan (Grant No. 18380094 and 19310124). We are grateful to Prof. Masahiro Chigira in Kyoto University, Prof. Xiyong Wu in Southwest Jiaotong University, Dr. Fanyu Zhang in Lanzhou University, Prof. Oliver Korup in Potsdam University, Dr. Johannes Weidinger in Erkudok Institute/Museum of Gmunden, Dr. Maurice McSaveney and Dr. Chris Massey in GNS, New Zealand, for their 
help and valuable discussions in this work. Mr. Xianggui He is thanked for his help in measuring the ground temperature.

\section{References}

Burchfiel, B.C., Chen, Z., Liu, Y., Royden, L.H., 1995. Tectonics of the Longmen Shan and adjacent regions, central China, International Geological Review 37: 661-735.

Burchfiel, B.C., Royden, L.H., van der Hilst, R.D., Hager, B.H., 2008. A geological and geophysical context for the Wenchuan earthquake of 12 May 2008, Sichuan, People's Republic of China, GSA Today 18

CCTV (China Central Television), 2008. Website (http://www.cctv.com/english/20080908/106010.shtml). Accessed on 20 December, 2011.

Chen, G.Q., 2009. Study on mechanism of high speed \& long-distance movement of the debris from landslide induced by the 2008 Wenchuan earthquake, Sichuan, China. In (Konagai ed): Investigation report on the May $12^{\text {th }} 2008$, Wenchuan earthquake, China. 67-73.

Chigira, M., Wu, X.Y., Inokuchi, T., Wang, G., 2010. Landslides induced by the 2008 Wenchuan earthquake, Sichuan, China, Geomorphology 118: 225-238.

Dai, F.C., Xu, C., Yao, X., Xu, L., Tu, X.B., Gong, Q.M., 2011a. Spatial distribution of landslides triggered by the 2008 Ms 8.0 Wenchuan earthquake, China. Journal of Asian Earth Sciences 40: 883-895.

Dai, F.C., Tu, X.B., Xu, C., Gong, Q.M., Yao, X., 2011b. Rock avalanches triggered by oblique-thrusting during the 12 May 2008 Ms 8.0 Wenchuan earthquake, China. Geomorphology, 132(3-4):300-318

Deng, Q., Chen, S., Zhao, X., 1994. Tectonics, seismicity, and dynamics of the Longmen Shan Mountains and its adjacent regions, Seismological Geology 16: 389-403 (in Chinese).

Densmore, A.L., Ellis, M.A., Li, Y., Zhou, R., Hancock, G.S., Richardson, N., 2007. Active tectonics of the 
Beichuan and Pengguan faults at the eastern margin of the Tibetan Plateau, Tectonics 26: TC4005

Fan, X., van Westen, C.J., Korup, O., Gorum, T., Xu, Q., Dai, F., Huang, R., Wang, G., 2012. Transient water and sediment storage of the decaying landslide dams induced by the 2008 Wenchuan earthquake, China. Geomorphology 171-172, 58-68.

Gorum, T., Fan, X.M., van Westen, C.J., Huang, R.Q., Xu, Q., Tang, C., Wang, G., 2011. Distribution pattern of earthquake-induced landslides triggered by the 12 May 2008 Wenchuan earthquake. Geomorphology 133(3-4):152-167.

Hayashi, K., Suzuki, H., 2004. CMP cross-correlation analysis of multi-channel surface-wave data. Explor. Geophys., 35 (2004), pp. 7-13

He, H., Tsukuda, E., 2003. Recent processes of active fault research in China, Journal of Geography 112, 480-520.

Hu W., Xu Q., van Asch T.W.J., Zhu X., Xu Q.Q., 2014. Flume tests to study the initiation of huge debris flows after the Wenchuan Earthquake in S-W China. Engineering Geology, http://dx.doi.org/10.1016/j.enggeo. 2014.04.006.

Huang, R. Q., 2009. Mechanism and geomechanical models of landslide hazards triggered by Wenchuan 8.0

Earthquake. Chinese J. Rock Mech. Eng., 28:1239-1249

Huang, R., Fan, X., 2013. The landslide story, Nature Geosci., 6, 325-326, doi:10.1038/ngeo1806.

Huang, R.Q., Li, W.L., 2009. Analysis of the geo-hazards triggered by the 12 May 2008 Wenchuan Earthquake, China. Bulletin of Engineering Geology and the Environment 68:363-371.

Jia, D., Wei, G., Chen, Z., Li, B., Zeng, Q., Yang, G., 2006. Longmen Shan fold-thrust belt and its relation to the western Sichuan Basin in central China: new insights from hydrocarbon exploration, AAPG Bulletin 90: 1435-1447. 
Jia, Q., Jia, D., Zhu, A., Chen, Z., Hu, Q., Luo, L., Zhang, Y., Li, Y., 2007. Active tectonics in the Longmen thrust belt to the eastern Qinghai-Plateau and Sichuan Basin: evidence from topography and seismicity, Chinese Journal of Geology 42: 31-44.

Li, X.P., He, S.M.., Luo, Y., Wu Y., 2012. Simulation of the sliding process of Donghekou landslide triggered by the Wenchuan earthquake using a distinct element method. Environmental Earth Sciences 65: 1049-1054.

Ma, L.F. (ed.), 2002. Geological atlas of China, Geological Publishing House, 348p

Maneval, D.R., 1969. Recent advances in extinguishment of burning coal refuse banks for air pollution reduction. Proceedings, Symposium on Pollution Control in Fuel Combustion, Processing and Mining, Minneapolis, MN, pp. $27-41$.

Park, C.B., Miller, R.D., Xia, J., 1999. Multichannel analysis of surface waves. Geophysics, 64 (3), 800-808.

Peng, M., Zhang, L.M., Chang, D.S., Shi, Z.M., 2014. Engineering risk mitigation measures for the landslide dams induced by the 2008 Wenchuan earthquake. Engineering Geology, http://dx.doi.org/10.1016/j.enggeo. 2014.03.016

Qi, S.W., Xu, Q., Lan, H.X., Zhang, B., Liu, J.Y., 2010. Spatial distribution analysis of landslides triggered by 2008.5.12 Wenchuan Earthquake, China. Engineering Geology, 116(1-2): 95-108.

Sassa, K., Wang, G., Fukuoka, H., 2003. Performing undrained shear tests on saturated sands in a new intelligent type of ring shear apparatus, Geotechnical Testing Journal 26: 257-265.

Sun, P., Yin, Y.P., Wu, S.R., 2009a: Experimental study on shear strength of rocks from Donghekou Landslide in dried state and saturated state. Geol. Bull. China, 28: 1163-1167.

Sun, P., Zhang, Y.S., Yin, Y.P., 2009b. Discussion on long runout sliding mechanism of Donghekou landslidedebris flow. Journal of Engineering Geology, 17: 737-744

Tang, C., Zhu, J., Qi, X., Ding, J., 2011. Landslides induced by the Wenchuan earthquake and the subsequent 
strong rainfall event: A case study in the Beichuan area of China. Engineering Geology 122(1-2): 22-33.

USGS (U.S. Geological Survey), 2008. Web site (http://earthquake.usgs.gov/eqcenter/eqinthenews /2008/us2008ryan/), accessed on 20 December, 2011.

Wang, F.W., Sun, P., Highland, L., Cheng Q.G., 2012. Initiation and motion mechanism of the Donghekou rapid and long runout landslide triggered by the 2008 Wenchuan earthquake, China. In: Earthquake-Induced Landslides, Proc. Int'l Symp. Earthquake-Induced Landslides (eds. Ugai, Yagi, and Wakai), Kiryu, Japan. pp.473-483.

Wang, G., Huang, R.Q., Chigira, M., Wu, X.Y., Lourenço S.D.N., 2013a. Landslide amplification by liquefaction of runout path material after the 2008 Wenchuan (M8.0) earthquake, China. Earth Surface Processes and Landforms, 38:265-274

Wang, G., Huang, R.Q., Kamai, T., Zhang F.Y., 2013b. The internal structure of a rockslide dam induced by the 2008 Wenchuan $\left(M_{w}\right.$ 7.9) earthquake, China. Engineering Geology 156: 28-36.

Wang, Y. S., Xu, H. B., Luo, Y. H., and Wu, J. F., 2009. Study of formation conditions and toss motion program of high landslides induced by earthquake, Chinese J. Rock Mech. Eng., 28, 2360- 2368 (in Chinese).

Xu, Q., Tang, M.G., 2009. Donghekou landslide, Qingchuan. In (Xu et al. eds): Large-scale landslides induced by the Wenchuan Earthquake, Science Press, Beijing.221-263

Xu, Q., Pei, X.J., Huang, R.Q., 2009. Large-scale landslides induced by the Wenchuan Earthquake. Science Press, Beijing, 473p (in Chinese).

Yin, Y.P., 2008. Researches on the Geo-hazards triggered by Wenchuan Earthquake, Sichuan, Journal of Engineering Geology 16: 433-444 (in Chinese).

Yin, Y.P., Wang, F.W., Sun, P., 2009. Landslide hazards triggered by the 2008 Wenchuan earthquake, Sichuan, China. Landslides 6(2):139-152 
Yin, Y.P., Zheng, W.M., Li, X.C., Sun, P., Li, B., 2011. Catastrophic landslides associated with the M8.0 Wenchuan earthquake. Bulletin of Engineering Geology and the Environment 70:15-32

Yu, B., Wu, Y.F., Chu, S.M., 2014. Preliminary study of the effect of earthquakes on the rainfall threshold of debris flows. Engineering Geology, http://dx.doi.org/10.1016/j.enggeo.2014.04.007

Yu, G.H., Xu, X.W., Klinger, Y., Diao, G.L., Chen, G.H., Feng, X.D., Li, C.X., Zhu, A.L., Yuan, R.M., Guo, T.T., Sun, X.Z., Tan, X.B., An, Y.F., 2010. Fault-Scarp Features and Cascading-Rupture Model for the Wenchuan Earthquake (Mw 7.9), Eastern Tibetan Plateau, China. Bulletin of the Seismological Society of America, 100(5B, pp. November 2010, doi: 10.1785/0120090255

Yuan, R.M., Tang, C.L., Hu, J.C., Xu, X.W., 2013. Ejection mechanism of the Donghekou landslide triggered by the 2008 Wenchuan Earthquake revealed by discrete element modeling. Natural Hazards and Earth System Sciences Discussions, 1:7667-7700, doi:10.5194/nhessd-1-7667-2013

Zhang, L.M., Xu, Y., Huang, R.Q., Chang, D.S., 2011. Particle flow and segregation in a giant landslide event triggered by the 2008 Wenchuan earthquake, Sichuan, China. Nature Hazards Earth System Sciences 11: 1153-1162.

Zhang, L.M., Zhang, S., Huang, R.Q., 2014a. Multi-hazard scenarios and consequences in Beichuan, China: The first five years after the 2008 Wenchuan earthquake. Engineering Geology, http://dx.doi.org/10.1016/j.enggeo.2014.03.020.

Zhang, S., Zhang L.M., Glade T., 2014b. Characteristics of earthquake- and rain-induced landslides near the epicenter of Wenchuan earthquake. Engineering Geology, 175: 58-73.

Zhang, Y.B., Chen, G.Q., Zheng, L., Li, Y.G., Wu, J., 2013. Effects of near-fault seismic loadings on run-out of large-scale landslide: A case study. Engineering Geology, 166: 216-236

Zheng, G.D., Xu S., Liang S.Y., Shi P.L., Zhao J., 2013. Gas emission from Qingzhou River after the 2008 
Wenchuan Earthquake, Southwest China. Chemical Geology, 339: 187-193.

Zhou, J.W., Cui, P., Yang, X.G., 2013. Dynamic process analysis for the initiation and movement of the

Donghekou landslide-debris flow triggered by the Wenchuan earthquake. Journal of Asian Earth Sciences, 76:

70-84

Zhou, X.C., Du J.G., Chen Z., Cheng J.W., Tang Y., Yang L.M., Xie C., Cui Y.J., Liu L., Yi L., Yang P.X., Li

Y., 2010. Geochemistry of soil gas in the seismic fault zone produced by the Wenchuan Ms8.0 earthquake, Southwestern China. Geochemical Transaction, 11(5):

Zhu, B.L., Wu, X.Y., 2012. Weathering process of black strata and formation of corrosive environmental water.

Procedia Environmental Sciences 12: 984-990. 
Caption:

Fig. 1 Epicenter of the quake and distribution of landslides that occurred during the quake

Fig. 2 Simplified geological map of the earthquake area (after Ma, 2003)

Fig. 3 Donghekou landslide: (a) oblique aerial view; (b) view from the toe part before the quake; (c) Longitudinal section along the main sliding path (after Yin 2008). W: location of landsliding witness; B1: toe part of the valley where the material started to move almost at the same time as the earthquake. B2: location of middle slope; B3: main source area of Donghekou landslide. L1, L2, L3, L4: S-wave survey lines. Arrow presents the extending direction of the survey line.

Fig. 4 (a) Fume on the landslide deposits near location of B1 in Fig. 3b (Taken on March 6, 2009); (b) "burned" slate rocks (Taken on March 6, 2009); (c) weathered slate rocks (Taken on July 19, 2012); (d) sulfur on the fumarole (Taken on May 21, 2009).

Fig. 5 Ground temperature $(-1 \mathrm{~m})$ in 2009.

Fig. 6 (a) Shear-wave velocity (Vs) profile along traverse line L4; (b) the view of side slope

Fig. 7 Shear-wave velocity (Vs) profiles along traverse line L2 (a) and L1 (b), respectively.

Fig. 8 Shear-wave velocity (Vs) profile along traverse line L1

Fig. 9 Idealized slope (a) and cyclic loading applied in the undrained test (b).

Fig. 10 Results of cyclic shear tests on saturated sandy soil from the deposit area 
Figures:

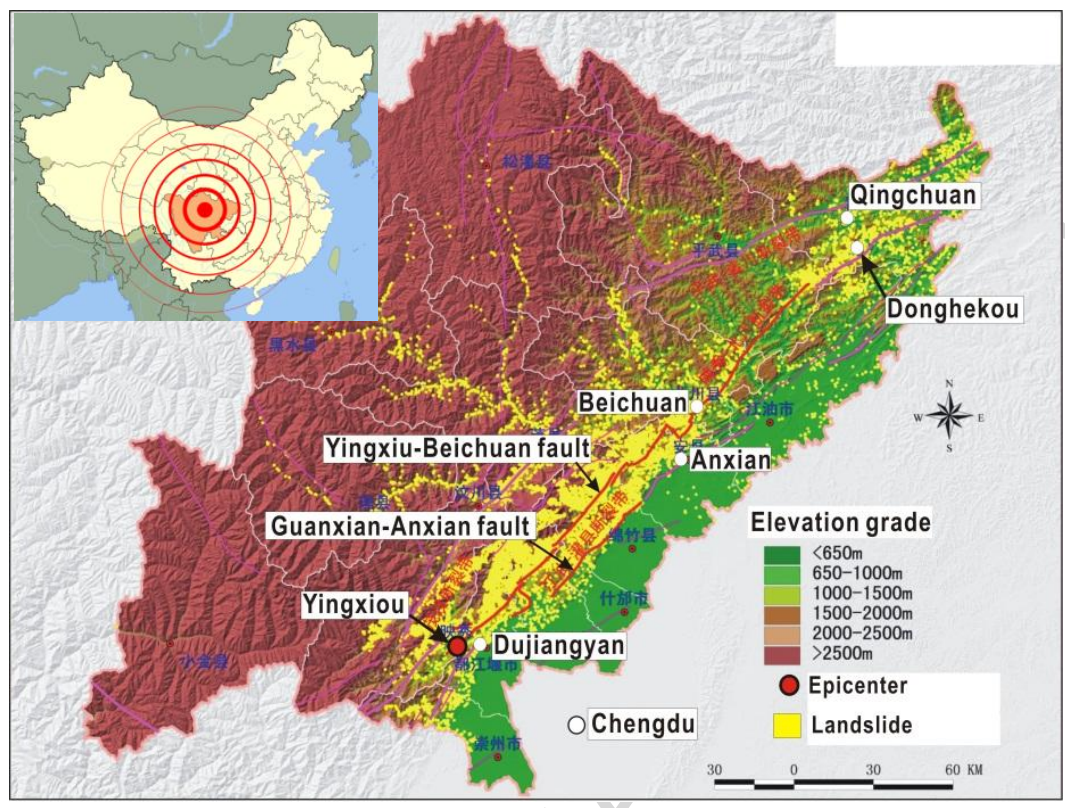

Fig. 1 Epicenter of the quake and distribution of landslides that occurred during the quake 


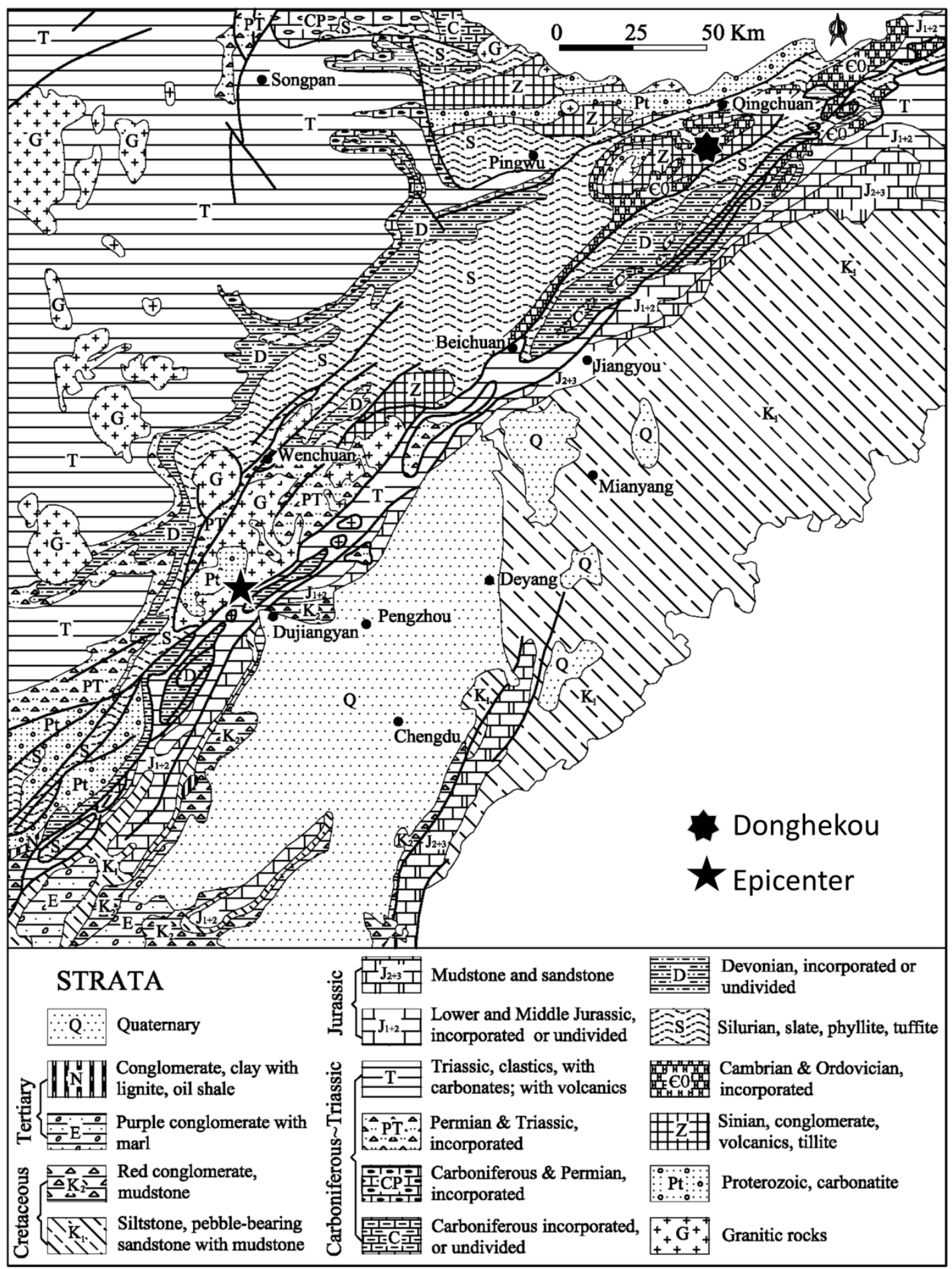

Fig. 2 Simplified geological map of the earthquake area (after Ma, 2003) 

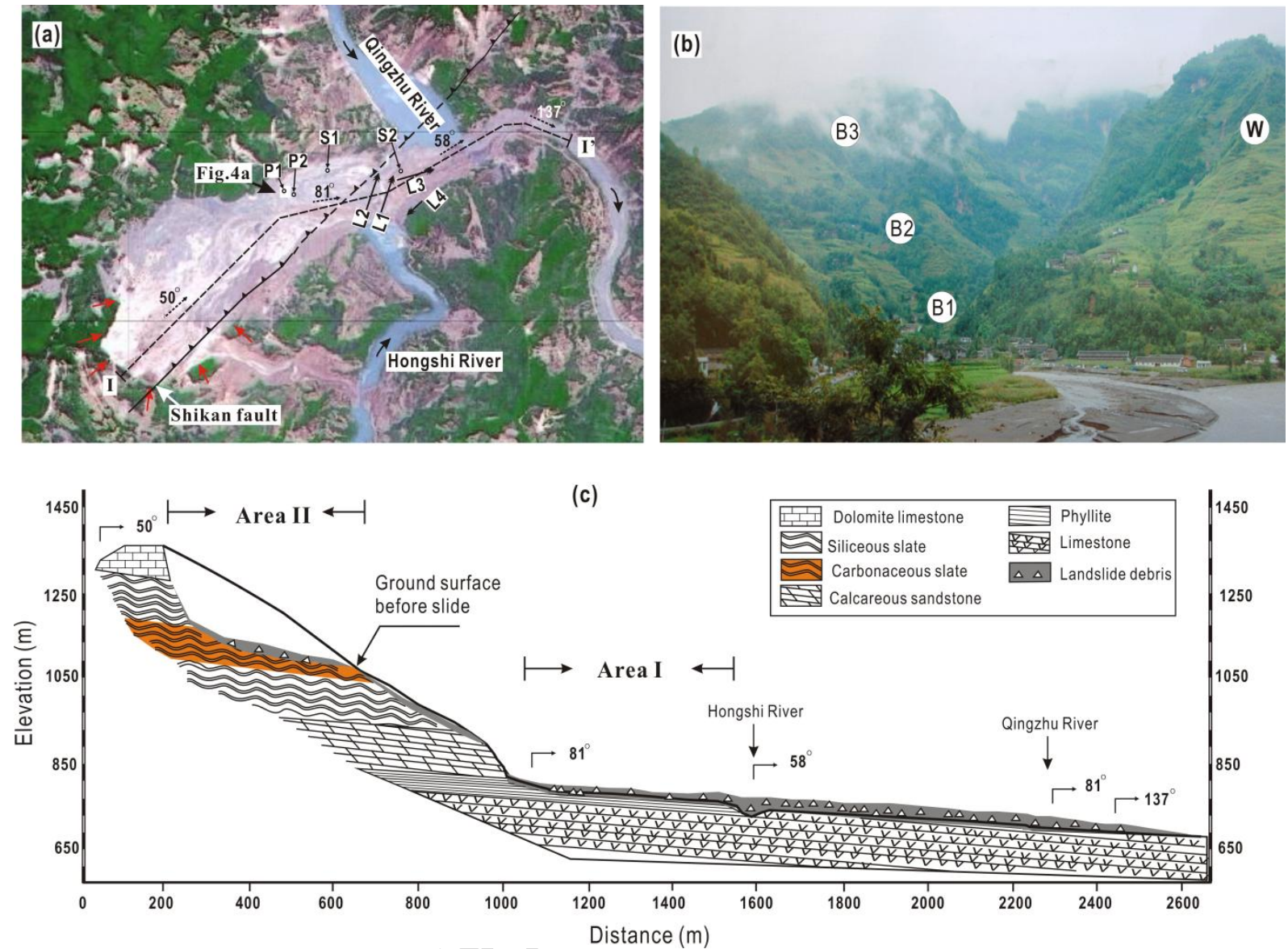

Fig. 3 Donghekou landslide: (a) oblique aerial view; (b) view from the toe part before the quake; (c) Longitudinal section along the main sliding path (after $\mathrm{Xu}$ and Tang, 2009). P1, P2: locations of ground temperatures were measured; S1, S2: sampling points for geotechnical tests; W: location of landsliding witness; B1: toe part of the valley where the material started to move almost at the same time as the earthquake. B2: location of middle slope; B3: main source area of Donghekou landslide. L1, L2, L3, L4: S-wave survey lines. Arrow presents the extending direction of the survey line. 

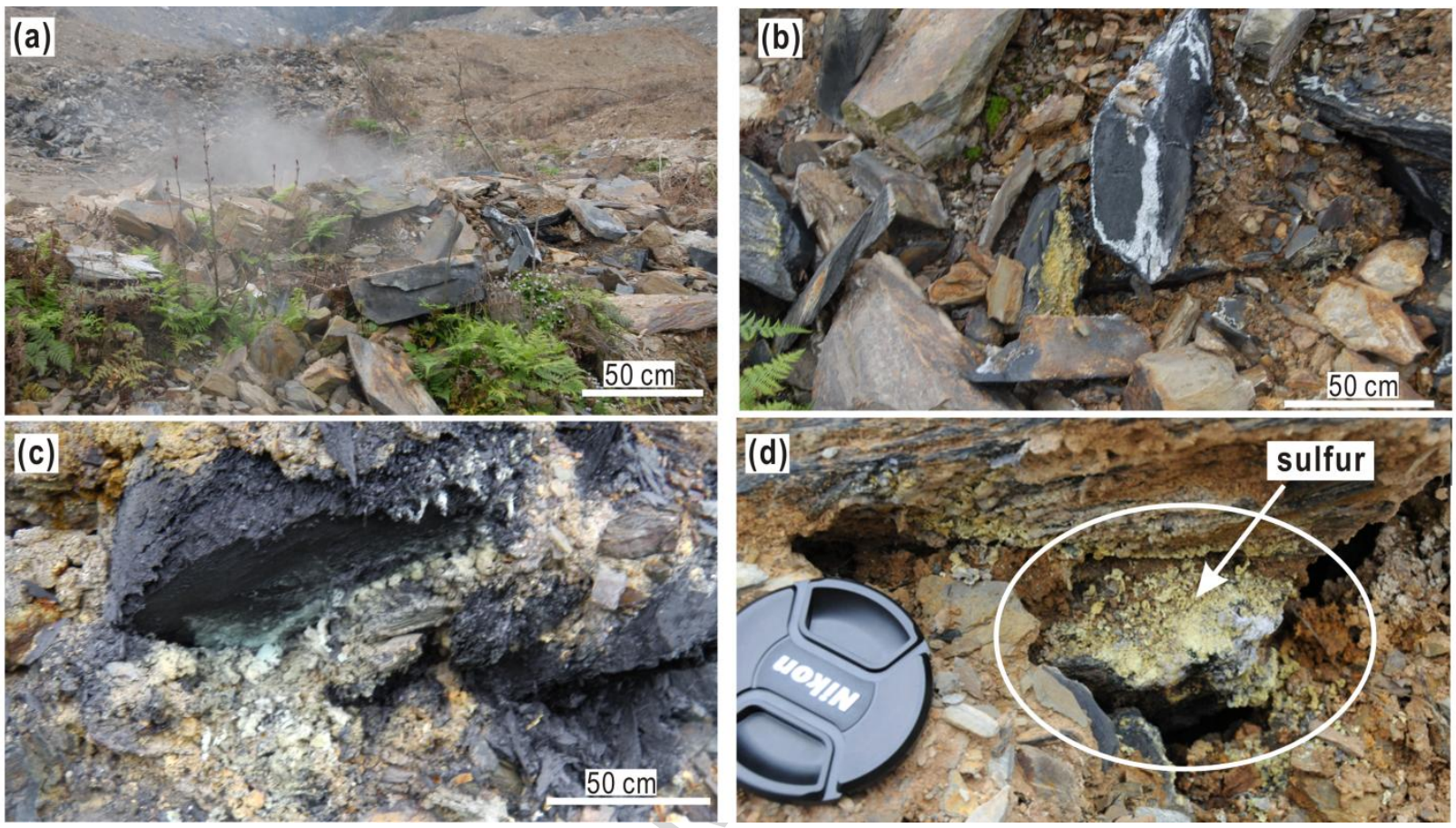

Fig. 4 (a) Fume on the landslide deposits near location of B1 in Fig. 3b (Taken on March 6, 2009); (b) "burned" slate rocks (Taken on March 6, 2009); (c) weathered slate rocks (Taken on July 19, 2012); (d) sulfur on the fumarole (Taken on May 21, 2009).

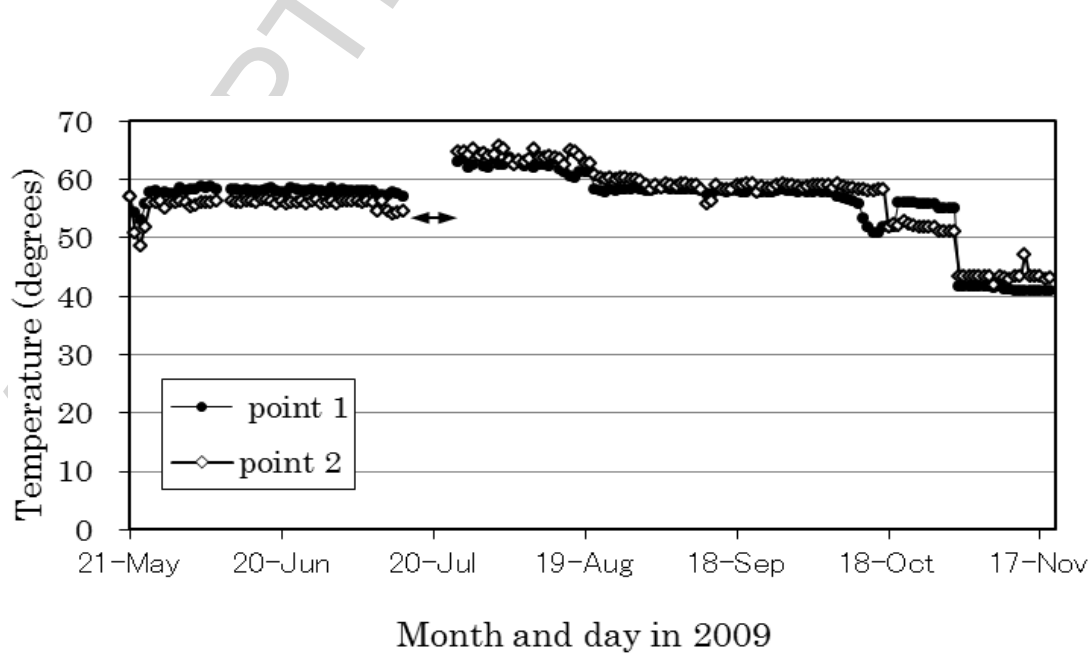

Fig. 5 Ground temperature (-1 m) in 2009. 


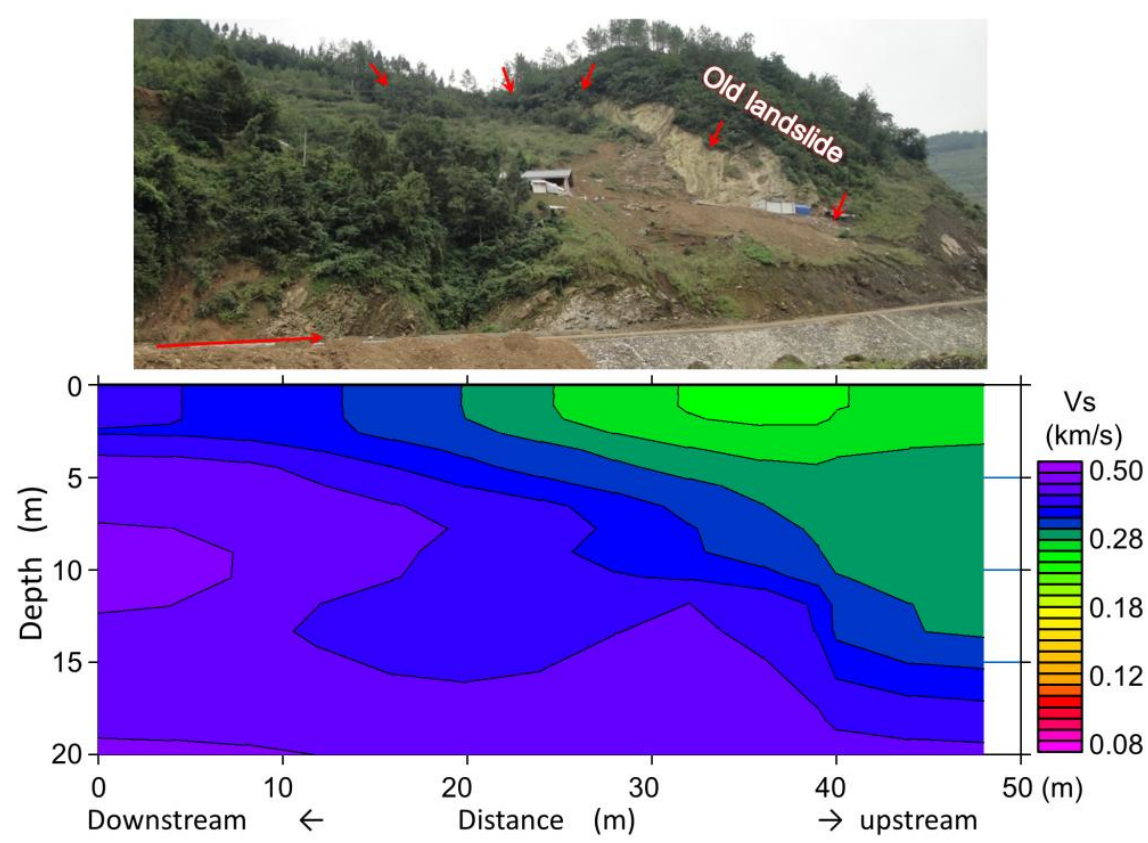

Fig. 6 (a) Shear-wave velocity (Vs) profile along traverse line L4; (b) the view of side slope

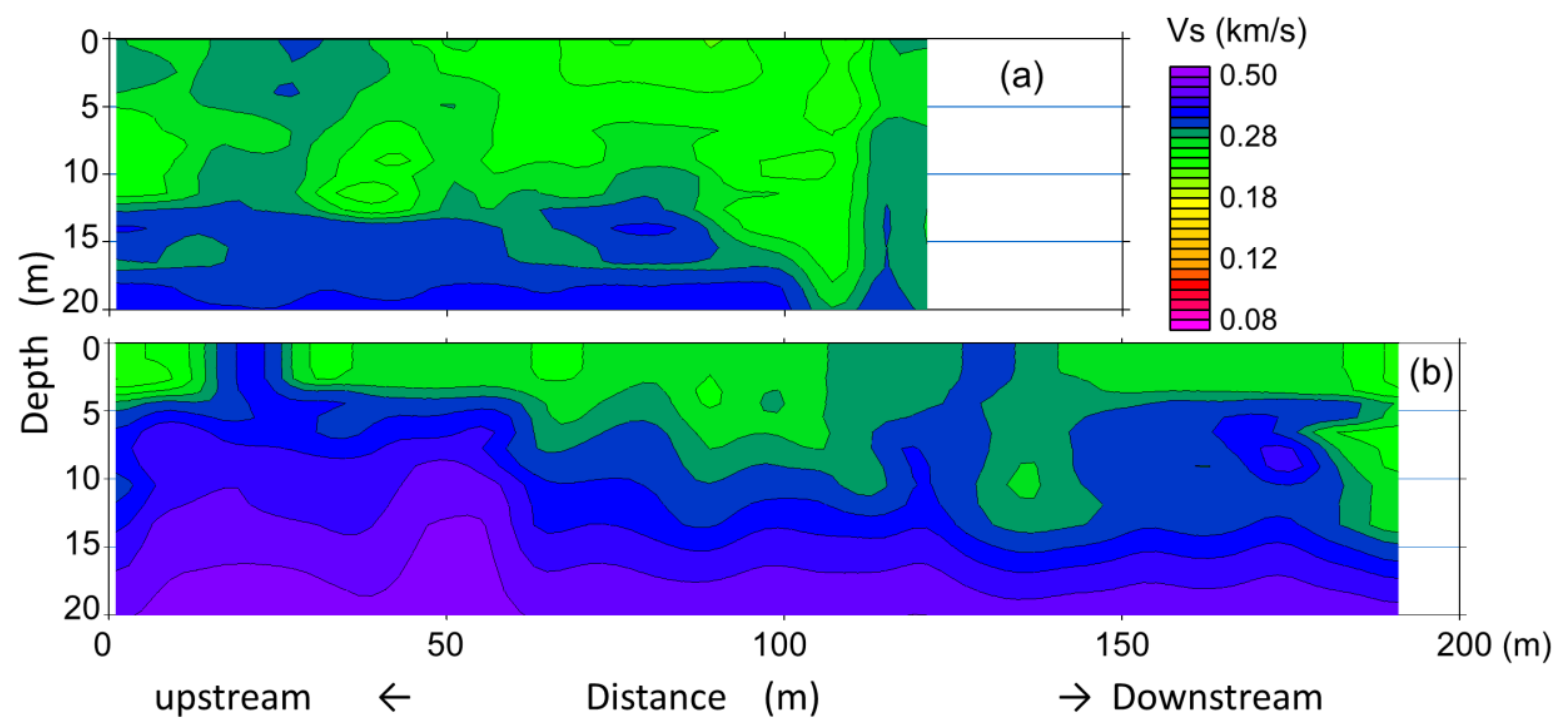

Fig. 7 Shear-wave velocity (Vs) profiles along traverse line L2 (a) and L1 (b), respectively. 

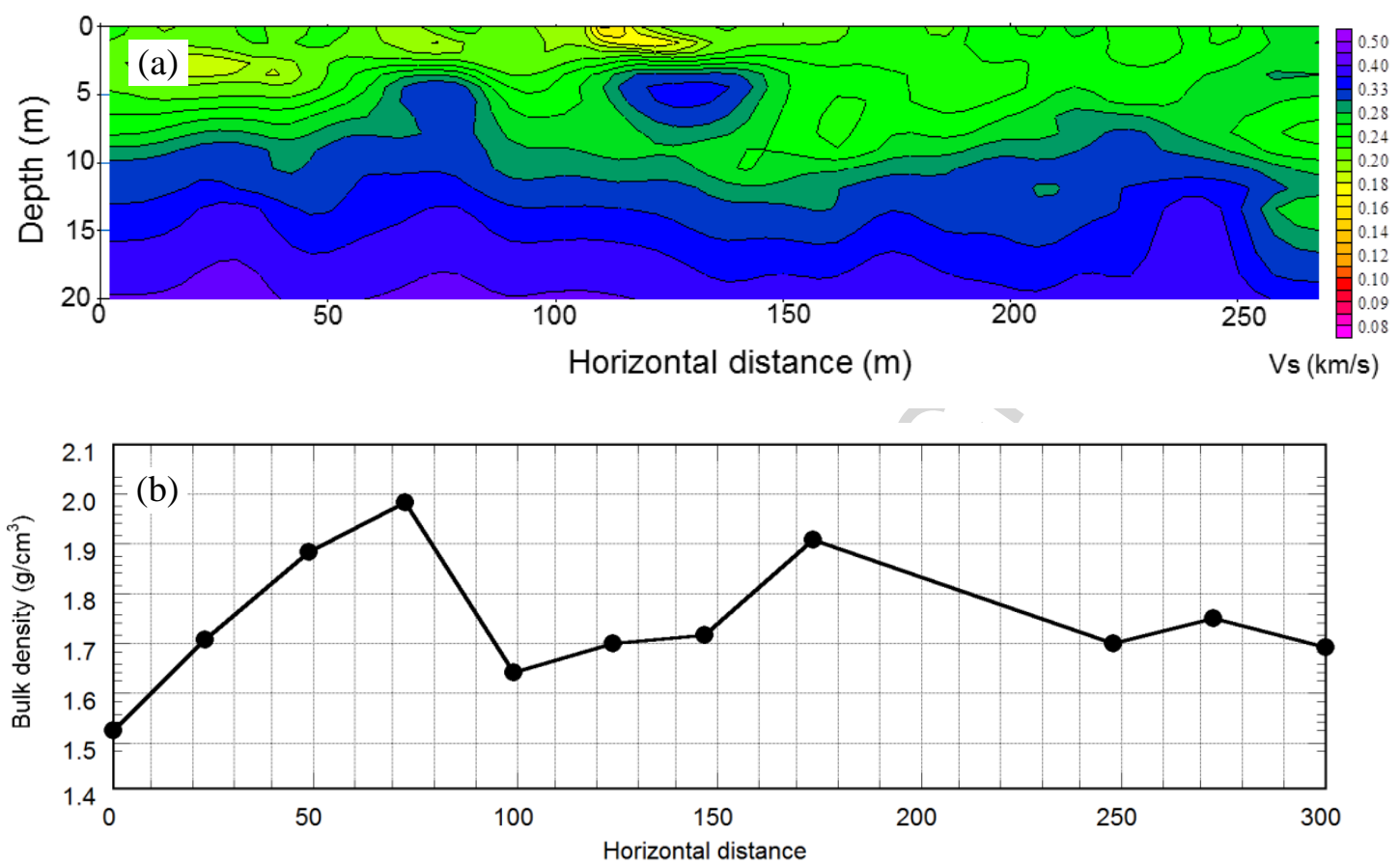

Fig. 8 (a) Shear-wave velocity (Vs) profile along traverse line L1; (b) Variation of bulk density along the main sliding direction with origin starting from survey line L1 approximately (after Zhang et al., 2011)
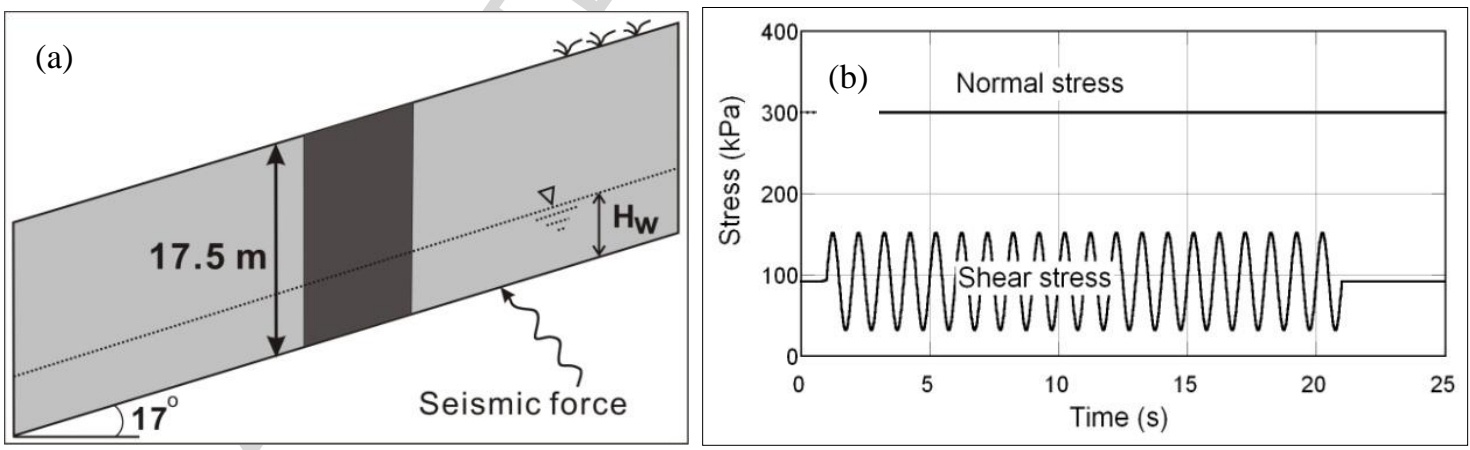

Fig. 9 Idealized slope (a) and cyclic loading applied in the undrained test (b).

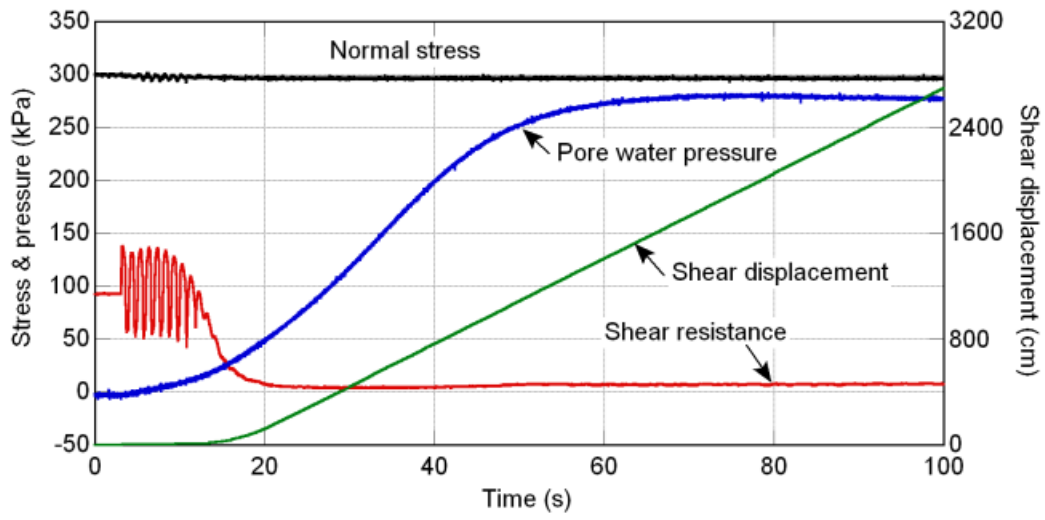

Fig. 10 Results of cyclic shear tests on saturated sandy soil from the deposit area 
Highlights

Donghekou landslide is a complex rock avalanche with high mobility

$>$ Weathering of outcropped slate resulted in fume with high ground temperature

$>$ Internal structure of the landslide deposits was surveyed

$>\quad$ Liquefaction of runout path material elevated the mobility of displaced debris 